\title{
Flutamide Induced Liver Injury in Female Patients
}

\author{
Nikola Malešević, Goran Bokan, Vlado Đajić
}

\section{ABSTRACT}

Flutamide is the active substance of the drug and belongs to the group of drugs that have antiandrogenic effect. Flutamide prevents the action of male sex hormones, i.e. suppresses the action of testosterone and dihydrotestosterone. Primarily, the indications for the use of flutamide refer to males and the treatment of advanced prostate cancer. It is also used in the treatment of patients with testicles surgically removed, and in patients who have not responded to another type of therapy or do not tolerate other types of treatment. The efficacy of flutamide has also been proven in the treatment of acne, hirsutism and alopecia in men and women with polycystic ovaries. It is important to emphasize that flutamide can cause severe side effects, above all liver damage, so it is not justified to use it in the treatment of conditions other than prostate cancer. Numerous data on hepatotoxicity (retrospective, prospective studies, case reports, surveillance study) were available in literature, which ranged from asymptomatic to acute, fulminant hepatitis that ended in transplantation, i.e. fatal outcome. In our paper, a review of the literature with case reports of notably hepatotoxicity is presented along with a case from our clinical practice.

Keywords: Flutamide, Drug Induced Liver injury, Fulminant hepatitis, Liver transplant, Liver toxicity.

Published Online: September 14, 2020

ISSN: $2593-8339$

DOI: $10.24018 /$ ejmed.2020.2.5.476

Nikola Malešević*

Cardiology Clinic, University Clinical

Center of Republic of Srpska, Banja

Luka, Bosnia and Herzegovina.

University of Banja Luka, Faculty of Medicine.

(e-mail: nikolamalesevic7@gmail.com)

Goran Bokan

Internal Medicine Clinic, Department of

Gastroenterology and Hepatology,

University Clinical Center of Republic of

Srpska, Banja Luka, Bosnia and

Herzegovina.

University of Banja Luka, Faculty of Medicine.

(e-mail: bokan.goran@yahoo.com)

Vlado Đajić

Neurology Clinic, University Clinical Center of Republic of Srpska, Banja Luka, Bosnia and Herzegovina.

University of Banja Luka, Faculty of Medicine.

*Corresponding Author

\section{INTRODUCTION}

Flutamide (FLU) is a non-steroidal oral antiandrogen, that acts by competitive inhibition of the binding of testosterone and dihydrotestosterone to the intracellular androgen receptor [1]. Flutamide was approved for use in therapy of prostate cancer [2]. Flutamide's antiandrogen effects have also been applied to the therapy of hyperandrogenic states both in men and women, including acne, hirsutism, and alopecia in women with polycystic ovarian syndrome (PCOS) [3], [4]. The incidence of flutamide-induced hepatotoxicity is $<0.18 \%$ [1], [5]. There is concern about idiosyncratic FLU hepatotoxicity, which can result in cholestasis, jaundice and liver necrosis and has also rarely necessitated liver transplantation or led to death [6]-[8]. Because of the potentially serious hepatotoxicity of flutamide, its use outside of therapy of malignant disease is not recommended [9].

This paper consolidates hepatotoxicity cases in female patients from 1993 to 2011 with different outcomes and presents a case report from our clinical practice.

\section{CASE PRESENTATION}

Our case was a 52-year-old woman who was referred to an endocrinologist for treatment of hormone imbalance. The doctor prescribed flutamide $375 \mathrm{mg}$ a day for the first month and $250 \mathrm{mg}$ a day for the second month) without preliminary tests to check liver function. At the end of the first cycle (lasting 2 months), the prescription was renewed (250 $\mathrm{mg}$ a day for another 2 months). No hematological tests were performed. She was not taking any other drugs and abstained from alcohol.

Nearly 3 months after the start of treatment, the woman presented many symptoms: nausea, vomiting, dark urine, pale stool, pruritus and jaundice. Blood tests showed raised concentrations of aminotransferase enzymes (aspartate aminotransferase $912 \mathrm{IU} / \mathrm{L}$, alanine aminotransferase $971 \mathrm{IU} / \mathrm{L}$, $\gamma$-glutamyl transpeptidase $375 \mathrm{IU} / \mathrm{L})$ and increased total bilirubin $(203,8 \mu \mathrm{mol} / \mathrm{L})$. The patient was immediately admitted. 
After exclusion of viral or toxic hepatitis, acute hepatitis due to flutamide use was diagnosed. Flutamide withdrawal was followed by reduction and normalization of aminotransferase levels. One year later, control FibroScan showed grade 3 steatosis and grade 1 fibrosis.

\section{DISCUSSION}

Flutamide is an antiandrogenic drug that is completely absorbed from the digestive tract and is usually well tolerated in most patients. Diarrhea occurs in a certain number due to poor tolerability, but its side effects are much more significant, manifested in the form of hepatotoxicity [10].

In the past, this drug has had a much wider application in both sexes. In women, it has been used in the treatment of acne, hirsutism, alopecia and PCOS [1], [2]. While in men, its use is justified only in advanced forms of prostate cancer. The mechanism of action of the drug is competitive inhibition of the binding of testosterone and dihydrotestosterone to intracellular androgen receptors that block the activity of endogenous androgens [7], [11].

There are numerous retrospective and prospective studies, case reports, surveillance studies in the literature that support the hepatotoxicity of Flutamide. We emphasized the review of the literature and singled out case reports of hepatotoxicity in female patients, and we also presented a case from our clinical practice.

The incidence of flutamide-induced hepatotoxicity is less than $0.18 \%$ and it is an idiosyncratic hepatotoxic mechanism that can manifest as a predominantly hepatocellular or predominantly cholestasis type of damage [1], [5]. According to the severity of clinical manifestations, the range of manifestations of side effects ranges from asymptomatic to acute, fulminant hepatitis, i.e. acute liver failure, up to a lethal outcome. Cases of death have also been reported after liver transplantation [12], [13].

Table 1 presents a review of literature spanning from 1993 to 2011, which describes cases of hepatotoxicity after the use of flutamide in female patients. The youngest patient who developed acute liver damage, i.e. a severe clinical picture, was fourteen years old and fully recovered after a liver transplant [14].

Osculati et al. [17] in 2006 presented the case of an eighteenyear-old patient with a severe form of hepatotoxicity who died after a liver transplant. According to data from the literature [12], [13], [15], [16], [18] recorded cases of hepatotoxicity with moderate and severe clinical picture ended in complete recovery.

In a relatively recent study, Brahm et al, presented seven patients with hepatotoxicity, with an average age of 29.1 years (range 20-44 years). Five of the seven patients had severe liver damage and underwent liver transplantation, one of whom died. Two patients who had fully recovered had had a milder clinical form [7].

Compared to other authors, the patient from our case report is the oldest reported case of hepatotoxicity in women who reached complete recovery of liver function after discontinuation of the drug.

TABLE 1: HEPATOTOXICITY OF FLUTAMIDE IN FEMALE PATIENTS; REVIEW OF

\begin{tabular}{|c|c|c|c|}
\hline \multicolumn{4}{|c|}{ CASE REPORTS } \\
\hline $\begin{array}{l}\text { Case report } \\
\text { study }\end{array}$ & Age & $\begin{array}{c}\text { Severity of } \\
\text { hepatotoxicity }\end{array}$ & Outcome \\
\hline $\begin{array}{c}\text { Wallace et al } \\
{[12]}\end{array}$ & 20 years & Moderate-severe & Heal \\
\hline $\begin{array}{l}\text { Wysowski et } \\
\text { al [13] }\end{array}$ & 46 years & Severe & Heal \\
\hline $\begin{array}{l}\text { Andrade et } \\
\text { al [14] }\end{array}$ & 14 years & Severe & $\begin{array}{l}\text { Liver transplantation; } \\
\text { Heal }\end{array}$ \\
\hline Garcia & & & \\
\hline $\begin{array}{c}\text { Cortés et al } \\
{[15]}\end{array}$ & 14 years & Severe & Heal \\
\hline $\begin{array}{l}\text { De Amorim } \\
\text { et al [16] }\end{array}$ & 21 years & Mild & Heal \\
\hline $\begin{array}{l}\text { Osculati et al } \\
{[17]}\end{array}$ & 18 years & Severe & $\begin{array}{l}\text { Liver transplantation; } \\
\text { Death }\end{array}$ \\
\hline $\begin{array}{c}\text { Castelo- } \\
\text { Branco et al } \\
{[18]}\end{array}$ & 26 years & Severe & Heal \\
\hline $\begin{array}{c}\text { Brahm et al } \\
{[7]}\end{array}$ & $\begin{array}{c}\text { 29,1 years } \\
\text { (range: } 20-44 \\
\text { years); } \\
7 \text { patients }\end{array}$ & $\begin{array}{l}5 \text { out of } 7: \text { Severe } \\
2 \text { out of } 7: \text { Mild }\end{array}$ & $\begin{array}{c}5 \text { Liver } \\
\text { transplantation } \\
1 \text { Death } \\
\text { Heal }\end{array}$ \\
\hline
\end{tabular}

\section{IV.CONCLUSION}

By careful selection of available data - cases and detailed analysis of our clinical case, it can be concluded that flutamide has the only justified use in the treatment of prostatic tumor. Simply put, its use is not justified in females in the treatment of acne and hirsutism. The spectrum of hepatic impairment caused by flutamide varies from moderate to severe, and the end result after discontinuation of therapy ranges from complete cure to fatal consequences.

\section{REFERENCES}

[1] Giorgetti R, di Muzio M, Giorgetti A, Girolami D, Borgia L, Tagliabracci A. Flutamide-induced hepatotoxicity: ethical and scientific issues. Eur Rev Med Pharmacol Sci. 2017;21(1 Suppl):69-77.

[2] Reilly DR, Delva NJ, Hudson RW. Protocols for the use of cyproterone, medroxyprogesterone, and leuprolide in the treatment of paraphilia. Can J Psychiatry 2000; 45: 559-563.

[3] POCS Australian Alliance. Evidence-based guideline for the assessment and management of polycystic ovary syndrome. Clayton: The Jean Hailes Foundation for Women's Health; 2011. Available from: http:// www.med.monash.edu.au/epidemiology/news/ sept2nded/evidencebased-guideline-polycystic-ovary-syndrome.pdf.

[4] Cassero-Branco C, Moyano D, Gómez O, Baasch J. Longterm safety and tolerability of flutamide for the treatment of hirsutism. Fertil Steril 2009; 91: 1183-8.

[5] Manso G, Thole Z, Salgueiro E, Revuelta P, Hidalgo A. Spontaneous reporting of hepatotoxicity associated with antiandrogens: Data from the spanish pharmacovigilance system. Pharmaco Epidemiol Drug Saf 2006; 15: 253-9.

[6] Cetin M, Demirci D, Unal A, Altinbas M, Guven M, Uluhizarci K. Frequency of flutamide induced hepatotoxicity in patients with prostatic carcinoma. Hum Exp Toxicol 1999; 18: 137-40.

[7] Brahm J, Brahm M, Segovia R, Latorre R, Zapata R, Poniachik J, et al. Acute and fulminant hepatitis induced by flutamide: case series report and review of the literature. Ann Hepatol 2011; 10:93-8.

[8] LiverTox: Clinical and Research Information on Drug-Induced Liver Injury [Internet]. Bethesda (MD): National Institute of Diabetes and Digestive and Kidney Diseases; 2012-. Flutamide. [Updated 2017 Jul 5]. Available from: https://www.ncbi.nlm.nih.gov/books/NBK548908/. 
European Journal of Medical and Health Sciences

www.ejmed.org

[9] Higuchi S, Kobayashi M, Yano A, Tsuneyama K, Fukami T, Nakajima M, Yokoi T. Involvement of Th2 cytokines in the mouse model of flutamide-induced acute liver injury. J Appl Toxicol 2012; 32: 815- 822.

[10] Teppner M, Boss F, Ernst B, Pahler A. Application of lipid peroxidation products as biomarkers for flutamide-induced oxidative stress in vitro. Toxicol Lett 2015; 238: 53-59.

[11] Castelo-Branco C, Hernandez-Angeles C, Alvarez-Olivares L, Balasch J. Long-term satisfaction and tolerability with low-dose flutamide: a 20-year surveillance study on 120 hyperandrogenic women. Gynecol Endocrinol 2016; 32: 723-727.

[12] Wallace C, Lalor EA, Chik CL. Hepatotoxicity complicating flutamide treatment of hirsutism. Ann Intern Med 1993; 119: 1150.

[13] Wysowski DK, Fourcroy JL. Flutamide hepatotoxicity. J Urol 1996; 155: 209-212.

[14] Andrade RJ, Lucena MI, Fernandez MC, Suarez F, Montero JL, Fraga E, Hidalgo F. Fulminant liver failure associated with flutamide therapy for hirsutism. Lancet 1999; 353: 983.

[15] Garcia Cortes M, Andrade RJ, Lucena MI, Sanchez Martinez H, Fernández MC, Ferrer T, Martin-Vivaldi R, Pelaez G, Suarez F, RomeroGomez M, Montero JL, Fraga E, Camargo R, Alcantara R, Pizarro MA, García-Ruiz E, Rosemary-Gomez M. Flutamide-induced hepatotoxicity: report of a case series. Rev Esp Enferm Dig 2001; 93: 423-432.

[16] De Amorim MFD, de Amorim WPD, Duques P, de Amorim PD, de Vasconcelos JR. Flutamide-induced hepatotoxicity during treatment of acne - A case report. An Bras Dermatol 2005; 80: 381-384.

[17] Osculati A, Castiglioni C. Fatal liver complications with flutamide. Lancet 2006; 367: 1140-1141.

[18] Castelo-Branco C, Del Pino M. Hepatotoxicity during low-dose flutamide treatment for hirsutism. Gynecol Endocrinol 2009; 25: 419-422. 